\title{
Interpretation: New Focus within Literary Research
}

\author{
Julieta Leo \\ Universidad de Monterrey \\ ORCID ID: oooo-0oo3-4180-2985. Email: julieta.leo@udem.edu
}

Received July 31, 2017; Revised September 13, 2017; Accepted September 17, 2017; Published September 20, 2017.

\begin{abstract}
The differences and difficulties found upon doing literary research are analyzed. The fact that researchers also interpret is highlighted as well as the need for sufficient time and freedom to do their research. The use of adequate selection criteria, the subjectivity and intuition of the exegete, as well as the use of concepts such as respect for the literal meaning (Umberto Eco) and the analogy of proportion (Inger Enkvist) are proposed as appropriate guidelines for establishing renovated, but systematic reading of texts.
\end{abstract}

Keywords: literary theory, hermeneutics, research strategies, reading.

It must be pointed out - although it is almost obvious - that the purpose of a scientific paper is to communicate something concrete, not moods, personal opinions or subjective feelings. Nevertheless, it is also true that in some ways all written expression is formed by ideas conceived from the viewpoint of an author's subjectivity and personal style. In addition, these will never completely be free of dominant opinions and prejudices and they are subject to the imprecision of the language used. Consequently, literary research never attempts to be absolutely objective, a task that is not possessed by this science.

The fundamental purpose of this paper is to point out some of the differences and difficulties found in literary research. Upon addressing this, it may be possible to better understand the characteristics of literary studies and the nature of projects related to the humanities. It must be clarified that the reflections presented are the result of experience in the area, specifically, the result of a research project on the novel, Paradiso, written by the Cuban author, José Lezama Lima.

Juana Inés in Respuesta a Sor Filotea states: "I do not study to be able to write, and even less to be able to teach (which, in me, would be colossal arrogance) but rather only to see if by studying I can be less ignorant. Thus, I respond and this is what I feel." (2001, p. 444). So, without any other ambition than to demonstrate the honesty and frankness of this declaration, a similar feeling can be felt when doing research projects and it is important that this be indicated before getting started with the topic. The objective is to share experiences in literary research that seem to confirm Umberto Eco's (1998a) arguments concerning the results of research ${ }^{1}$.

Literary research differs with respect to other types of research. It cannot be argued that literary research is more complicated; but its differences may help to better understand the characteristics of literary papers, including final evaluation projects, dissertations, monographs,

(C) AesthetixMS 2016. This Open Access article is published under a Creative Commons Attribution Non-Commercial 4.0 International License (http://creativecommons.org/licenses/by-nc/4.0/), which permits non-commercial re-use, distribution, and reproduction in any medium, provided the original work is properly cited. For citation use the DOI. For commercial re-use, please contact editor@rupkatha.com. 
or graduate theses. One must first begin with the use that is frequently given to the word "Research".

\section{Confusion of the term.}

There are different classifications of "research" activities. For example, it is said that a professor "researches" when he evaluates the result of teaching and students do "research" when they consult an encyclopedia. There can be a request (from a private institution, company or from a government agency) behind a research paper in which the desired result is clear from the beginning. It is necessary to indicate that this in some manner diminishes the merit of the original meaning of research. This use of the word "research" almost indiscriminately to all work that involves searching for something decreases, to a certain extent, the prestige of systematic and independent research based on an itemized evaluation of sources.

Literary research, along with almost all other humanistic disciplines, has what Inger Enkvist very aptly refers to as an "inferiority complex when compared to the exact sciences" (2003, "Elecciones éticas y estéticas", para. 2). For that reason, it is understandable that whoever does research has the obligation to shape it with a focus that makes it appear as scientific as possible. One way to achieve this has been to do research on data in an orderly manner that permits systemization; for example, the presence of certain baroque techniques (hyperboles, metaphors, paradoxes, the grotesque ...), although this type of research does not delve into understanding the work studied. In other words, the humanly important aspect is abandoned in lieu of limited research or research that is of little interest, but it is, at the same time, irreproachable from a methodological point of view. In an attempt to clarify this, the author's personal experience with Paradiso is presented.

\section{The case of Paradiso: love at first sight.}

Studies of this work show that researchers within the field of literature are very conscious of that which is politically correct. With someone as distinctive as José Lezama Lima, there are at least several acceptable academic attitudes: the first, is to start with the idea that Lezama is a baroque (or neo-baroque) writer and, for that reason, someone doing research on his work also studies all manifestations of that which is baroque. By reproducing and commenting on the author's opinions, the researcher demonstrates that he/she is "committed" and academically efficient (within the studies on Lezama's Paradiso, this group of researchers is relatively large).

The second is research that observes and comments on the controversial aspects of Paradiso, but it is research that does not become involved in an unorthodox discussion. These researchers choose to write long and linguistically well-constructed texts in which the risqué aspect is so well-hidden that no expert notices it. These researchers can state to themselves and to experienced colleagues that they have mentioned the aspects in question, thus escaping controversy

When immersed in doing research for this novel, it was noticed that there are very few truly critical articles, if "critical" is understood as a writer who wants, knows and dares to question the author's work or articles written by other critics. Among the papers published, only a handful of them sincerely question the proposals in Lezama's work and those found in his own statements. Stated another way: There is interest in questioning how much authors' articles contribute to the advancement of knowledge of works such as Paradiso. 
Having stated that, perhaps researchers cannot criticize Lezama because they do not have sufficient knowledge and, it must be pointed out that this is not necessarily due to a lack of ability, but it is instead due to a lack of time. This is the critical point of this paper. It is necessary to recognize that time is needed to be able to develop a well-defended critical study concerning the work of an author who has written a lot, whose style is complex and who mixes elements from very diverse areas. In this sense, some papers converted the author's writings or papers written by other researchers into summaries, and, it is quite possible that they do not deserve to be referred to as research. Very often, readers of articles later ask themselves: What did the author want to express? It is difficult not to think that the true reason for writing was to fulfill a requirement or to present another publication ${ }^{1}$.

After studying Paradiso and critical texts published on this novel, it becomes clear that researchers who write about the novel have had to make numerous choices. The essential aspect for attempting to understand it is to observe and take into consideration infinite approaches to the novel and admitting (not accepting) the numerous angles and, occasionally, controversial exegetic angles that characterize it. Reading, understanding the novel, and doing research on it implies a long journey that can very easily take several years.

Although research projects can be one's own choice, this type of choice does not necessarily lead to a safe port. The serene ocean can become stormy. To begin with, Lezama is not who he seems to be at first glance. Detailed study shows that his image was constructed for marketing purposes and it was in keeping with the times. At that time Cortázar (1984) —of recognized prestige - wrote an article defending Paradiso and that was enough for the world to notice him and to leave him alone ${ }^{2}$. Since then, different publishers have been interested in maintaining this "official" image which is problematic if one considers the content of his work. It is paradoxical, even ironic, since it is known that Lezama was very careful concerning statements about him as a person ${ }^{3}$. When selecting the line of research, one may think that it is simple to state things exactly as seen but it is much more difficult than can be imagined. To discover that the object under study is the opposite of what one believes requires much more than humility and courage.

Research or investigation is etymologically derived from vestigium which means to go after a footprint or down a trail; this means that during the trajectory the purpose can be modified and the result may differ from what one had hoped to find. Thus, it is necessary to seek other clues, other hints to follow the newly discovered path and this results in a research paper that can provide another way to gain access to the novel. This is when the study will be based on hermeneutics.

\section{Interpretation and limits in hermeneutic practice}

Without a doubt, as Luis Goytisolo (2001) states, each reader makes the work exist and each one understands life in a different manner. Hermeneutics is born precisely from polysemy because where unambiguousness exists there is no need for interpretation. However, upon reading a work one can oscillate between scarce curiosity and an inclination to suspect or one can to go too far in conflicting virtues. According to the logic of Eco (1998b), all systems originate in an interpretative hypothesis and, as a result, a system can in theory always be hypothesized which turns that disconnected into something plausible. In all cases, it is recommended that the hermeneutic game should follow a system of rules. 
Due to the characteristics of Paradiso and the specific aspect the novel dealt with, it was not easy to select points of view that were the most appropriate for supporting interpretative criteria. Extreme or absolute relativism of interpretation is not advocated and since that discussed is always an interpretative wager, two concepts were adopted to establish the limits of this hermeneutic exercise, one by Umberto Eco and the other by Mauricio Beuchot.

The concept respects the literal sense since Eco (1998b) assures us that within the borders of language there is a literal sense of lexical voices found in dictionaries or that which the man on the street would first define when he is asked concerning the meaning of a certain word. For that reason, he believes that any act of liberty by the reader can be produced after and not before the application of this restriction, although he admits that it is a point of great dispute (Eco, 1998b, p. 14).

The second concept uses the analogy of proportion. According to Beuchot (1997), proportionality attempts to gather the diverse contents of a term with proportional equality; in other words, with a certain democracy of meaning. This proportionality allows terms to be related to each other by some common point which closes a margin of variability. Taking into consideration that all variables have a range or margin beyond which they cannot escape, that range must be determined in some manner. There is no single meaning for this term but there are several meanings that can validly belong to it; but not in an indiscriminate manner (Beuchot, 1997, p. 38-44).

Upon stating that one respected the literal sense (Eco), one refers to the fact that if the author (Lezama) cites Isolde, one thinks of a mythological Celtic woman or Wagner and not of Snow White, pre-Colombian culture or Batman; in the same manner that Popol Vuh transports readers to Mexico and not to Denmark and Genesis will lead to the Bible and not to the Koran, to mention just a few examples. When presenting interpretative options, it is difficult to precisely indicate which of the terms were referred to specifically by Lezama, one will be guided by the context, according to the analogy of proportion (Beuchot), in establishing links to the passage that is being developed at that time.

In the same manner, to affirm that the phrase "el ibis de Ra" is found in Paradiso, it is necessary to find the complete occurrence of the phrase and not to structure the phrase from isolated elements, in other words, on page 1, the article "el", on page 50 the "ib" sequence in the body of the Iberian lexeme and, thus afterwards since with that method any affirmation could be found in any text. The same is true for anagrams - that for "Roma" is love and not stegosaurus (Eco, 1998b, p. 106). Based on that previously mentioned, it must remain clear that according to Maurizio Ferraris:

[. . . ] we all interpret and this does not mean that we are experts in hermeneutics, and moreover, we do not need to read treatises on hermeneutics to receive enlightenment on our praxis. In addition, a jurist, theologian or philologist certainly finds some hermeneutic moments in his activity, that is, however, not as far as hermeneutics is concerned, but in legal, theological or philological areas; in other words, a little or a lot of knowledge of hermeneutics does not guarantee me any knowledge of law, theology or literature, in the same way that some knowledge of semiotics does not assure me in any manner that there is mastery of medical symptomatology.

Thus, between the natural interpretative praxis and the codification of special hermeneutics, there is no essential relationship (no more than that found between one who speaks a language and a grammarian). (Ferraris, 2000, p. 22) 
If research is based on the arguments of Eco and Beuchot (and Ferraris) it is because they are authorities in the field of interpretation (hermeneutics), but it cannot be forgotten that upon strictly applying the two concepts mentioned and not the totality of their theoretical work; the purpose was to interpret and not to give an erudite digression concerning hermeneutics. "However, since each one is free to interpret many things in his/her manner, the problem of validity of the interpretation constitutes the obvious counterpart of an interpretation that is potentially exempt from any limit" (Ferraris, 2000, p. 35). And since this is an interpretation of Paradiso through its hermetic, esoteric and heterodox side, a topic which is very controversial in and of itself, it is prudent to establish rules and to keep within self-imposed limits.

This means that for this interpretative work one cannot ignore that Eco foresees the exegetes of Finnegans Wake which is a novel and as such it must support critical reading, but one must take into consideration that the author sweats to forge an immense machine for producing interpretations and he has the right to indicate reading paths, since he has not made a copy of a telephone book in which, thanks to the richness of its characters, we can all construct the Human Comedy as we want, but he has prepared and calculated each allusion and his writing demands that act of respect (Eco, 1998b, p. 121). In his opinion,

[. . .] the fact that Finnegans Wake foresees a model reader capable of finding infinite possible readings does not mean that the work does not have a secret code. Its secret code is in its hidden will-evident when it is translated in the terms of textual strategies-of producing that reader, free to venture into all of the interpretations he may desire, but obligated to surrender himself when the text does not sanction his most bawdy audacity. (Eco, 1998b, p. 41)

His recommendations were followed in the hermeneutic exercise used with Paradiso, appealing to a modus, to a measurement, in other words, it was structured within the limits of interpretation. And although the objective was "to reach a sensible and analogical mediation in which the intention of the author is safeguarded with the greatest possible objectivity but with the warning that our subjective intention is found present" (Beuchot, 1997, p. 21), nothing saves one from throwing oneself into a deep abyss. In all cases the reader will have the last word.

\section{The case of research as a proposal}

For research that arrives as a proposal, one specific case will be dealt with. From research on the influence of English literature in Spanish literature- taking into account the breadth of the topic - the first one that concerns (and occupies) us is that of leaving out relevant information. Selection criteria must be used, that is, a list can be made of authors and texts following a guideline, such as strict chronology; thus one can also make a selection by genre or topic. In this manner, the results are concrete; moreover, they can be systemized. For example, suggestions can be established to re-calculate the importance of the influence of English literature on Spanish literature and help professors to establish literary curricular connections with the educational model where they teach. How?: By reviewing proposals on the role of this literature through the work of William Shakespeare, delving into the effect due to the inclusion of readings by the English dramatist in university curriculum design ${ }^{4}$; however, it must be reiterated that it is necessary to remember that even as systematic as literary research may attempt to be, the road can branch off at any time.

Another example can be mentioned. In 2009, the year of the bicentennial of the birth of Edgar Allan Poe - an anniversary that no literary critic, student of letters or assiduous reader can 
ignore-it was posited that there was an influence of American literature on Latin American literature. Nothing could be farther from the truth and it is explained as follows.

For unexpected reasons, the topic of translating Poe's work and influence on Latin America was selected. It was decided to explore how these translations have contributed to the creation of an acute sense of that literature as something modern: modern in its concept, although profoundly rooted in past cultures. Extraordinary translations were mentioned, taking into account poets and writers of stature who have undertaken this, among which are found Baudelaire, Mallarmé and, of course, Julio Cortázar. During the research, among translations and multiple adaptations, it was discovered that a composer from Buenos Aires ${ }^{5}$ knew of Poe's work through Cortázar's translations and decided to write a ballad inspired by the translation of the story "The tell-tale heart" (1843-45). Someone recalled that a French composer had done a composition for the harp ${ }^{6}$ inspired by the original. The first composer was interested in the concept and as a good Latin American he adopts and adapts it to his context according to his artistic interest, and the second party is interested in "the rhythm", which she maintains according to her own criteria. There are contrasting perspectives, writings to be located and numerous clues to be followed: but only six months were given to present a concrete result.

And although nothing is comparable to the satisfaction of finding a solution to a problem that appears to be unsolvable, it does not end in the "solitude of triste-le-Roy" as does Erick Lönnrot (Borges, 1998, p. 153-172); it simply demonstrates that each finding affects the other, and a quality and careful analysis is an arduous task. That having been stated, everything is a question of honestly asking oneself: How long do I have to present the results?

It is worthwhile to review what Sor Juana wrote:

[. . .] And hence, I assert no excuse, nor do I claim one for having studied a variety of subjects; on the contrary, these aid one another. Rather, not having taken advantage of them is due to my ineptitude and the weakness of my intellect. The variety of my studies is not at fault. What indeed might testify in my defense is the hard work caused by having neither a teacher nor fellow students with whom I could confer and practice what I had studied. Instead, I only had a mute book for a teacher and an oblivious inkwell for a fellow student. And instead of explanations and exercises all I had was a lot of interruptions, not only related to my religious duties for you already know how usefully and profitably one spends time performing these duties --but also related to trivial community activities. For example, I would be reading and the sisters in the next cell would have a sudden urge to play instruments and sing. Or I would be studying and two maids would start quarreling and come in and tell me to arbitrate in their argument. Or I would be writing and a friend would come visit me while behaving very badly toward me but with very good intentions, in which case not only must one excuse the interference but also one must be grateful for the harm done. And this happens continually, for the moments I dedicate to my study are those left over from the community's regularly scheduled practices; and those extra moments are precisely when the others come and interrupt me. Only those who have experienced life in community know how very true this is; yet only by the strength of my vocation and because of the great love between me and my dear sisters is my nature able to find pleasure. Since there is union in love, then there can be no separating extremes in it. (de la Cruz, 2001, p. 450-451)

In the end, despite the truthfulness of the words of the tenth muse, Juana Inés de Asbaje y Ramírez de Santillana, it would difficult to be a hermetic Próspero dedicated to reading his books on a desert island (Bloom, 1996, p. 33). 


\section{Conclusions}

Finally, anyone who does research also interprets, thus, he/she must feel free to apply his/her own initiatives in a research paper. When writing, there must not be a reconstruction (focus of study) or an objectivity of style. There is a variety of moods engendered although the sentiments and passion that inspired the author cannot be consigned to words and there is no strict rule for this adaptation. Of course, to rediscover the simplicity of living forms is not an easy task, there must first be an echo of the spirit, and afterwards one must consciously do research to have a clear idea of the content. The interpreter, when doing research, rediscovers, and he brings life to that written through his personality.

Liberty arises from a laborious and renovated study, always pursuing truth in the same; working, experimenting, remembering that the clear path is always subject to change. The most important objective is to recreate the work, to give it life, to use intuition since this is what creates and directs the process.

Historical knowledge is interesting and of great use, but if one follows the path of "historical accuracy" one runs the risk of falling into disoriented interpretations. This is because one cannot recreate past sensitivity, since it was the author who had a live relationship with it. Writing is always in the present, it is not a fossil, and despite time and thanks to its grandeur it continues to speak to us and arouse emotions, since in all writing, without taking into consideration the era in which it was written, there is something in common, humanly and spiritually speaking.

In this manner, each reader will find his/her own way to understand the author's condition and spirit and try to establish a connection. Thus, the words become links in a chain, with value in and of themselves and, there is value due to the relationships that are established between that which has happened and that which will happen. True interpretation requires a present and personal concept, the fact that the author wrote what he felt, does not mean that he would not want to increase or improve the means of interpretation. To that respect Lezama affirmed: "It is an illusion to think that the author of a work is the one who can best penetrate his secrets. While his writing is in the oven, the creator dictates and receives a dictation; after the work is produced he can only exercise his gifts equally to whomever approaches his work" (Lezama, 1978, p. 712).

Thus, when one is involved in literary research projects - without regard to how one becomes involved in them - despite the ability to do an exhaustive bibliographic search, to organize the information collected, to describe, to narrate sources of the topic that is dealt with and to present the conclusions in a logical, orderly and pertinent manner, it is important to consider that if one wishes to effectively delve into that being studied, a pertinent choice is required. A choice that leads us to a better understanding of the literary work: it requires perseverance, humility, courage and time. And since Chronos is relentless, when working "against the clock" it is sensible and advisable is to establish objective limits (to make a deal with the calendar). Try, whenever possible, to assess what the journey teaches. In other words, enjoy or remain in each layover or in each port, because when research is lived as a challenge, it is soon discovered that it is an activity from which - as Eco assures-one reaps benefits in all attempts. 


\section{Acknowledgement:}

The first version of this work was published in the La Colmena, Revista de la Universidad Autónoma del Estado de México, number 89 (January-March 2016).

\section{Notes}

${ }^{1}$ For this, see my article "Paradiso, grimorio antillano de José Lezama Lima. Otra perspectiva del hermetismo en el lenguaje paradisiaco" (2009).

${ }^{2}$ See Cortázar (1984, p.15-16) for more information.

${ }^{3}$ To clarify that previously mentioned, see Álvarez (1984, p. 95) and Goytisolo (1976, p. 157).

${ }^{4}$ Darío, Lugones, Borges, Neruda, among others.

${ }^{5}$ Cerati (1988) wrote a song titled “Corazón delator" for Soda Stereo’s album Doble vida.

${ }^{6}$ The French Composer, Henriette Renié (1875-1956) wrote "Ballade Fantastique d'après «Le Coeur Révélateur» d'Edgard Poë" for the harp.

\section{References}

Álvarez Bravo, A. (1984). La novela de Lezama [Lezama's novel]. In Coloquio internacional sobre la obra de José Lezama Lima (vol I, pp. 87-98). Madrid, España: Espiral/Fundamentos.

Beuchot, M. (1997). Hermenéutica analógica [Analog hermeneutics]. México D.F., México: Facultad de Filosofía y Letras.

Bloom, H. (1996). Elegía al canon [An elegy fo the canon]. In El canon occidental (pp.25-51). Barcelona, España: Anagrama.

Borges, J. L. (1998). La muerte y la brújula [Death and the compass]. In Ficciones (pp. 153-172). Madrid, España: Alianza editorial.

Chicote, G., Dalmaroni, M. (2009). La investigación literaria: problemas iniciales de una práctica [Literary research: initial problems of a practice]. Santa Fe, Argentina: Ediciones UNL.

Cortázar, J. (1984). Encuentros con Lezama Lima [Encounters with Lezama]. In Coloquio internacional sobre la obra de José Lezama Lima (Vol. 3, pp. 11-20). Madrid, España: Espiral/Fundamentos.

------------. (2009). Alto fanal presente. In Papeles inesperados [Unexpected Writings]. México D.F., México: Alfaguara.

De la Cruz, J.I. (2001). Obras completas [Complete Works] (Vol. IV). México D.F., México: Fondo de cultura económica.

Eco, U. (1995). Interpretación y sobreinterpretación [Interpretation and overinterpretation]. Cambridge, Reino Unido: University Press.

------. (1998a). Cómo se hace una tesis. Técnicas y procedimientos de investigación, estudio y escritura [How to write a thesis]. Barcelona, España: Gedisa.

(1998b). Los límites de la interpretación [The limits of interpretation]. Barcelona, España: Lumen. 
Enkvist, I. (2003). Ética y estética en la investigación literaria [Ethics and aesthetics in literary research]. Espéculo: Revista de estudios literarios, 23. Retrieved from http://www.ucm.es/info/especulo/numero24/inv_lite.html

Ferraris, M. (1999). La hermenéutica [Hermeneutics]. Madrid, España: Taurus.

Fuentes, C. (2011). Estirpe de novelistas [Offspring of novelists]. El País. Retrieved from http://elpais.com/diario/2011/o8/27/babelia/1314403935_850215.html

Goytisolo, J. (1976). La metáfora erótica: Góngora, Joaquín Belda y Lezama Lima [The erotic metaphor: Góngora, Joaquín Belda and Lezama Lima]. Revista Iberoamericana, 2 (45), 158-175.

Goytisolo, L. (2001). La parte del lector [The reader's part]. El País. Retrieved from http://elpais.com/diario/2001/o9/25/opinion/1001368811_850215.html

Lezama Lima, J. (1978). Paradiso. México D.F., México: Colección Archivos.

Sontag, S. (1966) Contra la interpretación [Against interpretation]. Buenos Aires, Argentina: Alfaguara.

Velázquez. Spanish and English Dictionary. Chicago, United States: Follett Publishing Company.

Wanhón Bensusán, S. (Ed.) (2010). El problema de la interpretación literaria: Fuentes y bases teóricas para una hermenéutica constructiva [The problem of literary interpretation: Theoretical sources and bases for constructive hermeneutics]. Vigo, España: Editorial Académica del Hispanismo

Julieta Leo is a Professor-Researcher at the Department of Humanities at the University of Monterrey. She has been speaker at several universities and higher institutions in Mexico and abroad and invited to carry out research stays at the Universidad Complutense de Madrid. Among the honors received are the Mention in the Casa de las Américas Literary Prize in the Essay of Artistic-Literary Theme (La Habana, 2007), the UDEM Award for research in the area of Education and Humanities (2013), Prize of Research Linked to Teaching (2005-2012) and Award for Teaching Quality (2004). She was Jury of the National Prize of Sciences and Arts in the field of Linguistics and Literature in 2014. She is a member of the International Association of Hispanists (AIH), the Academy of Letters (UDEM), the Advisory Board of Higher Studies (IMNRC) and the H. P. Historical Society. Director of Domus Litterarum (2006-2008) and the literature magazine of the year 2004 to date. She is the author of numerous articles and the book "Las sagradas letras de Paradiso. Estudio sobre el hermetismo de José Lezama Lima" published by the Spanish publisher Oportet (2013). Invited by the UNEAC and the Cuban Book Institute to participate in the colloquium "Pensamientos en la Habana" (2016) on the occasion of the 5oth anniversary of the publication of Paradiso. 